\title{
Myzocallis walshii (Hemiptera: Sternorrhyncha: Aphididae), an exotic invasive aphid on Quercus rubra, the American red oak: Its bionomy in the Czech Republic
}

\author{
JAN HAVELKA and PETR STARÝ \\ Biological Centre, AS CR, Institute of Entomology, Branišovská 31, 37005 České Budějovice, Czech Republic; \\ e-mail: jhav@entu.cas.cz
}

Key words. Aphididae, Myzocallis walshii, Quercus, parasitoids, expansion, Czech Republic, exotic insects

\begin{abstract}
Myzocallis (Lineomyzocallis) walshii (Monell), a North American aphid species associated with Quercus rubra was detected for the first time in Europe in 1988 (France), and subsequently in several other countries - Switzerland, Spain, Andorra, Italy, Belgium and Germany. Recent research in 2003-2005 recorded this aphid occurring throughout the Czech Republic. The only host plant was Quercus rubra. The highest aphid populations occurred in old parks and road line groves in urban areas, whereas the populations in forests were low. The seasonal occurrence of the light spring form and the darker summer form of M. (Lineomyzocallis) walshii as well as their different population peaks were noted. Four native parasitoids species [Praon flavinode (Haliday), Trioxys curvicaudus Mackauer, T. pallidus Haliday and T. tenuicaudus (Starý)] were reared from M. (Lineomyzocallis) walshii.
\end{abstract}

\section{INTRODUCTION}

Accidental introductions and establishments of exotic species of aphids are occurring all over the world. Subsequently, they interact either with their formerly introduced original host plants, or local plant species, or both.

Myzocallis (Lineomyzocallis) walshii (Monell, 1879) is an arboricolous calaphidine aphid (Aphididae, Calaphidinae, Panaphidini) associated with red oak, Quercus rubra and a few other oak species in North America. This aphid was first detected in Europe in France in 1988 (Remaudière, 1989) and subsequently recorded in several other European countries, including the Czech Republic (J. Holman, pers. commun.).

This account presents original information on the aphid, its distribution, host plants, seasonal history, parasitoids, and interactions with the local environment in the Czech Republic. The occurrence of M. (Lineomyzocallis) walshii in the Czech Republic is discussed in relation to its over-all distribution and expansion in Europe.

\section{MATERIAL AND METHODS}

The exotic host tree species of North American origin (Quercus rubra, Q. coccinea, Q. palustris) and one native species $(Q$. robur) were sampled primarily to find Myzocallis (Lineomyzocallis) walshii. However, all the other trees (Quercus spp., Tilia spp., Betula spp., Carpinus spp, Ulmus spp., Alnus spp., Corylus avellana L., Juglans regia L., and Fagus sylvatica L.) hosting local calaphidine aphids were also sampled at the same locations to determine the parasitoid guild and possible interactions after the establishment of $M$. (Lineomyzocallis) walshii. These results supplemented earlier long term research on the parasitoids in the area (Starý, 1987, 1988, 2006).

The first detection of M. (Lineomyzocallis) walshii was accidental, occurred in autumn 2003 and was of high populations on Q. rubra in South Bohemia. Also, as at some localities $M$.
(Lineomyzocallis) walshii manifested peculiar population patterns in the spring of 2004, these populations were sampled repeatedly in the course of a whole year to determine the key population characteristics and the complete life cycle of the aphid.

Sampling was concentrated in the main areas of red oak, Quercus rubra distribution. Various environments, such as parks, roadsides and shelterbelts in fields, forest edges, groves and hedges were sampled. In particular, arboretums such as old parks around historical castles, old city parks and large forest groves were increasingly chosen, as the aphid was most abundant in these environments. In total, 52 localities were sampled and a number of them were repeatedly visited in the course of a season during 2003-2005.

Oak trees were tentatively determined to species in the field and samples were taken for the herbarium, to be later verified, if necessary. Aphids were preliminarily identified as well, but a representative sample of specimens was preserved in ethanol $(80 \%)$ for the later detailed examination in the laboratory. A number of aphid-infested leaves were sampled (minimally twenty samples). The aphid-infested parts were gently cut with scissors and placed in plastic translucent cages (size 250 c.c.) covered with nylon netting. In aphid-outbreak situations, however, the samples were much more extensive and large numbers of heavily attacked leaves were placed in plastic bags. These were kept in portable cold boxes and then transferred to the laboratory, where they were emptied into large-sized cages covered with nylon netting, and maintained at $+18^{\circ} \mathrm{C}$, about $70 \%$ R.H., and a $18 \mathrm{~h}$ photophase (fluorescent light). The samples were examined almost daily and parasitoid adults that emerged were collected in $80 \%$ ethanol for later identification. Samples were maintained for three weeks in the laboratory and, than, the litter plant material at the bottom of the cages were examined for parasitoid adults. The number of aphid samples was 150 . Parasitoids were reared from 27 samples, but not all the samples were of equal size.

Aphid taxonomy and nomenclature followed Remaudière \& Remaudière (1997), Nieto Nafría et al. (1997) and Quednau (1999). A distribution map of Myzocallis walshii was prepared 

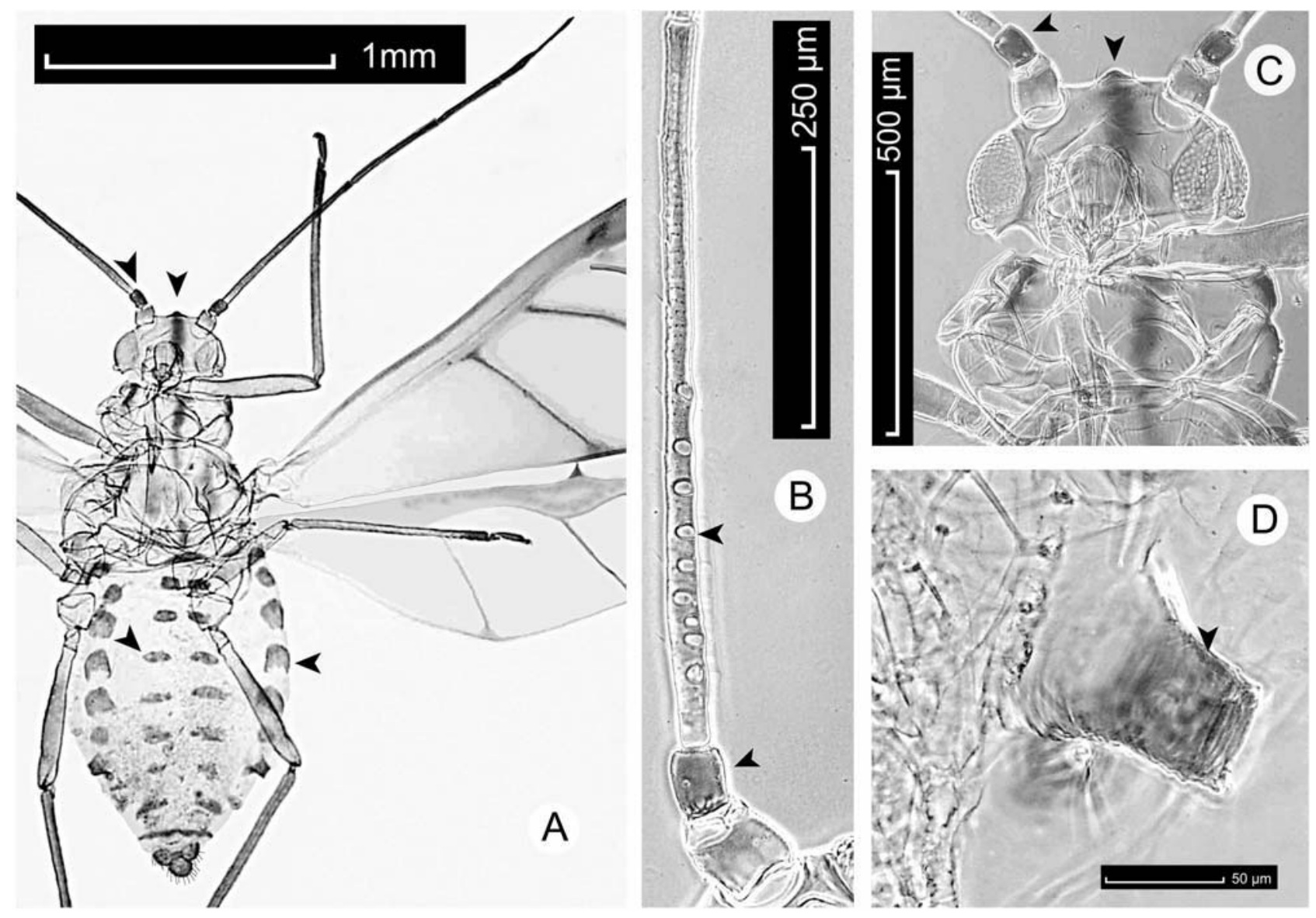

Fig. 1. Morphology of Myzocallis castanicola Baker, alate viviparous female: A - whole body; B - $3^{\text {rd }}$ antennal segment; C head; D - siphunculus.

according to the faunistic grid mapping system of Central Europe published by Pruner \& Míka (1996).

The voucher aphid material is deposited in the Laboratory of Aphidology (Biological Centre, AS CR, Institute of Entomology); the parasitoid material is in the collection of P. Starý (České Budějovice).

\section{RESULTS}

\section{General characteristics}

The holarctic genus Myzocallis includes 37 species of which only five occur in the Czech Republic. They are small $(1.5-2.0 \mathrm{~mm})$, delicate, usually yellowish aphids with a knobbed cauda and bilobed anal plate. The larvae usually have capitate dorsal hairs. The adult viviparae are all alate. The life cycle is monoecious and holocyclic. They are not ant-attended. The host plants are deciduous trees and bushes, especially catkin bearing trees or various families, e.g. Corylaceae, Fagaceae, and Myricaceae.

\section{Morphological characters}

The recently introduced nearctic species $M$. (Lineomyzocallis) walshii can be distinguished from the native and common M. (Agriomyzus) castanicola Baker, 1917 by the following morphological differences (Fig. 1A, C, D). Alate viviparous females of M. (Agriomyzus) castanicola have a distinct dark medial stripe on the head and thorax, black spots on abdomen, dark siphunculi and dark $2^{\text {nd }}$ antennal segment. The dark pigmentation is less distinct in the spring forms. The sides of pronotum and mesonotum of both species bear a black band extending from the eye to the base of hind wings (Fig. 2A). The late-summer form of $M$. (Lineomyzocallis) walshii has a broad band of black pigment foregrounding the costal vein in the forewing, which extends well past the stigma to the apex of wing (Fig. 2A). There are 5-7 secondary rhinaria on the 3rd antennal segment of M. (Agriomyzus) castanicola (but only 2-4 in M. (Lineomyzocallis) walshii) (Figs 1B, 2B). The spinal abdominal setae of embryos of M. (Agriomyzus) castanicola are long and overlap on tergites II-V (but short and non-overlapping in $M$. (Lineomyzocallis) walshii).

Colonies of $M$. (Lineomyzocallis) walshii live on the undersides of the leaves of Quercus rubra (Fig. 3A, B, C). In the Czech Republic, sexuales occur at the end of October and in November (Fig. 3D). M. (Agriomyzus) castanicola occurs on the undersides of leaves of Quercus and Castanea trees.

\section{Host plants}

No infestation of $M$. (Lineomyzocallis) walshii was recorded on other oak species ( $Q$. robur, $Q$. petraea, $Q$. palustris, $Q$. coccinea) isolated or co-existing with $Q$. rubra, at the localities sampled even when this aphid was 

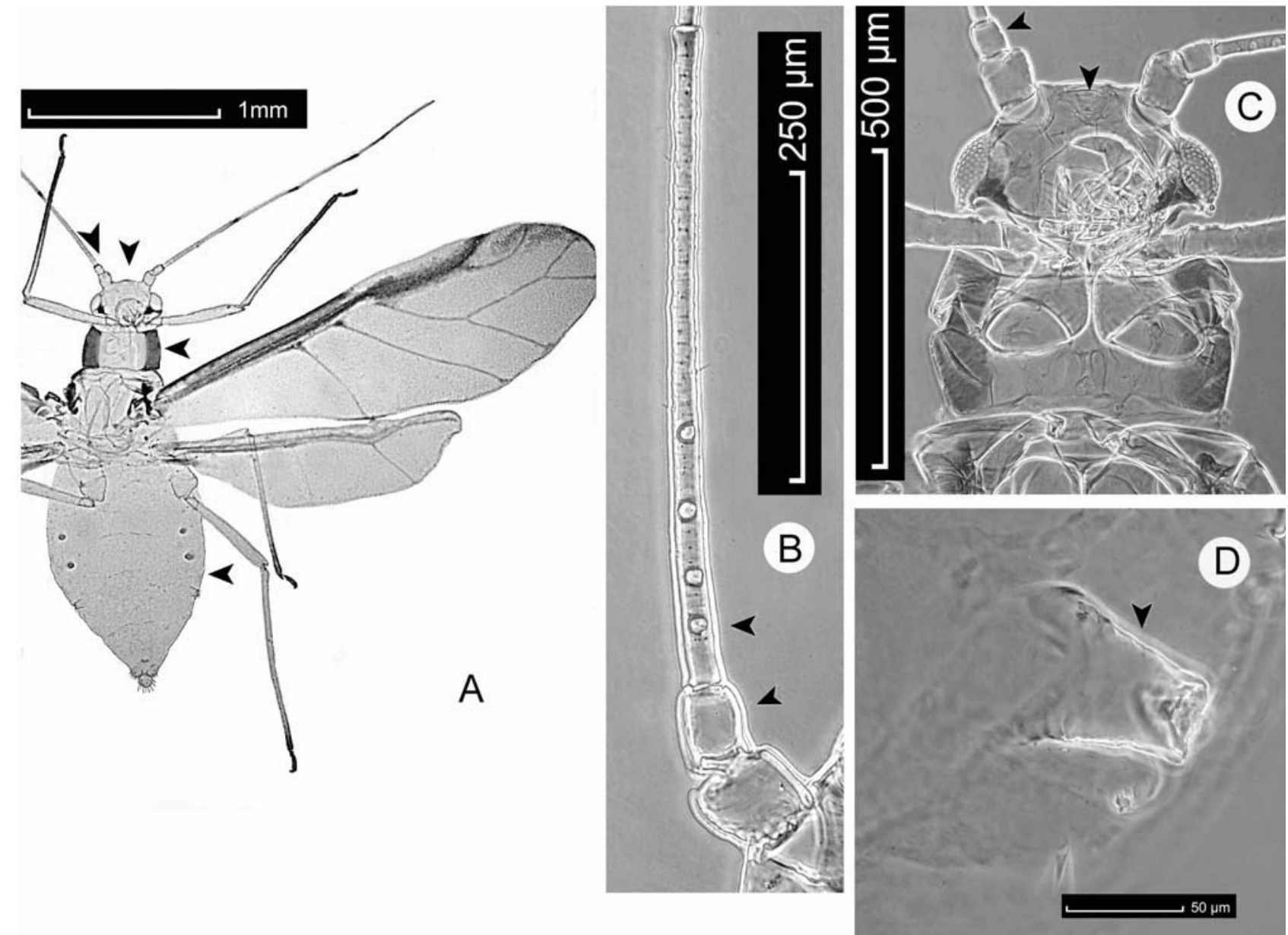

Fig. 2. Morphology of Myzocallis (Lineomyzocallis) walshii (Mon.), alate viviparous female late summer form: A - whole body; $\mathrm{B}-3^{\text {rd }}$ antennal segment; $\mathrm{C}-$ head; $\mathrm{D}$ - siphunculus.

abundant (both - spring and late-summer morphs) on $Q$. rubra.

Life cycle is presented in Fig. 4.

Obvious differences in the aphid morphs and in their seasonal occurrence were noted. The light-coloured spring form occurred early in the season, when the colonies were large and often covered the whole lower surface of leaves (Fig. 3A). They produced a large quantity of honeydew and moulds (Capnodium sp.) developed soon afterwards on the upper surfaces of the contaminated leaves. The lack of ant-attendance contributed to this phenomenon. Later in the season, the dark latesummer form occurred (from about August) at the same sites and on the same trees, but the colonies were less dense, less numerous on the older leaves. The honeydew contamination at this time was due to mainly high population of the spring form.

\section{Distribution}

Fig. 5 shows the localities in the Czech Republic where M. (Lineomyzocallis) walshii / Q. rubra was recorded: 5357 Semily, 5455 Mnichovo Hradiště, 5455 Sychrov, 5556 Suchorady, 5557 Sobotka, 5656 Jabkenice, 5856 Nymburk, 5856 Poděbrady, 5861 Vysoké Chvojno, 5941 Lázně Kynžvart, 5952 Praha, 5957 Kolín, 6042 Trstenice, 6058 Chedrbí, 6142 Planá u Tachova, 6243 Stř́ibro, 6253
Tožice, 6254 Benešov, 6256 Zruč n. Sáz., 6257 Bohdaneč, 6273 Nový Dvưr, 6344 Černotín, 6443 Horšovský Týn, 6455 Lukavec, 6442 Mirkov, 6543 Domažlice, 6455 Těchobuz, 6549 Blatná, 6571 Bystřice p. Host., 6573 Valašské Meziříčí, 6574 Rožnov p. Radh., 6670 Kroměříž, 6671 Dobrotice, 6753 Mažice, 6754 Soběslav, 6771 Zlín, 6851 Vodňany, 6854 Veselí n. L., 6855 Jindřichův Hradec, 6858 Telč, 6872 Luhačovice, 6952 Hluboká n. Vlt., 6953 Štěpánovice, 6954 Třeboň, 6955 Stříbřec, 6965 Židlochovice, 6969 Buchlovice, 7052 České Budějovice, 7055 Chlum u Třeboně, 7152 Český Krumlov, 7166 Lednice, 7253 Benešov n. Černou.

\section{Other aphid species on $Q$. rubra}

Lachnus roboris (Linnaeus, 1758): Two colonies on a young road-side $Q$. rubra tree (Mažice).

Myzocallis (Agrioaphis) castanicola Baker, 1917: Only a single specimen (nymph) was recorded on a young $Q$. rubra tree in a city park (Bystřice p. Hostýnem).

Thelaxes dryophila (Schrank, 1801): Five colonies on a young road-side $Q$. rubra tree (Mažice).

Tuberculatus (Tuberculoides) annulatus (Hartig, 1841): Only one colony was collected on a leaf of a young roadside Q. rubra tree (Soběslav). 

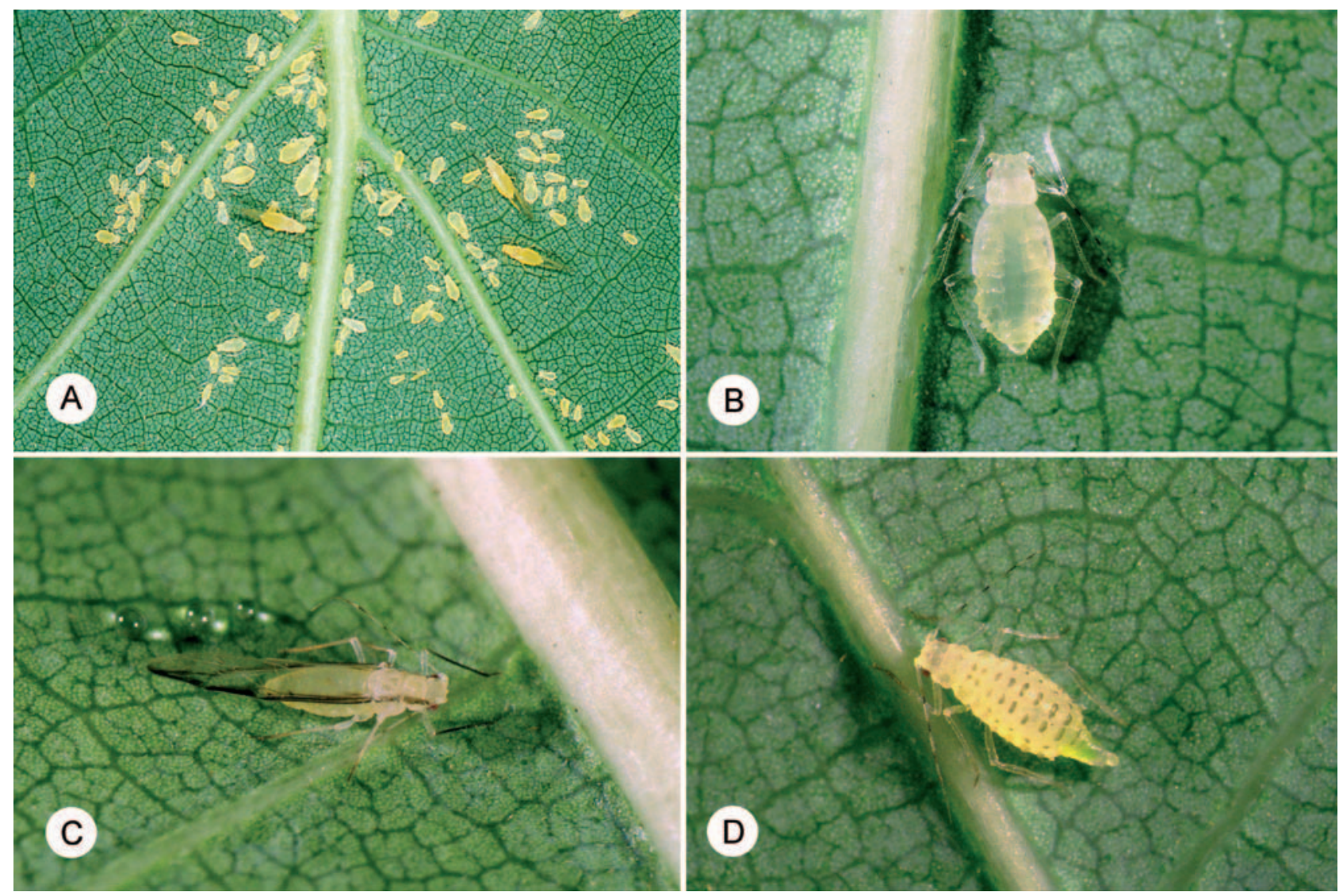

Fig. 3. Myzocallis (Lineomyzocallis) walshii (Mon.) aphids on Quercus rubra: A - colony of alate viviparous females on the underside of a leaf; B - nymph of alate viviparous female - summer form; C - alate viviparous female - summer form; D - ovipara in autumn.

\section{Parasitoids}

A review of the associations of local parasitoids with M. (Lineomyzocallis) walshii / Q. rubra together with a broader complex of calaphidine aphids / plant associations is presented in Table 1. M. (Lineomyzocallis) walshii is attacked by at least four native parasitoid species, which are more or less oligophagous on tree dwelling calaphidine aphids.

A total of 373 parasitoids were reared from M. (Lineomyzocallis) walshii on $Q$. rubra, and their relative abundance (\%) was: Praon flavinode (Haliday, 1833) - 0.3, Trioxys curvicaudus Mackauer, 1962 - 6.7, T. pallidus Haliday, 1833-89.0, T. tenuicaudus Starý, 1978 - 4.0.

Other aphid-parasitoid associations on the red oak were investigated in the Czech Republic: Lachnus roboris - no parasitoids reared, Myzocallis castanicola - no parasitoids reared, Thelaxes dryophila - Adialytus thelaxis (Starý, 1961) Tuberculatus (Tuberculoides) annulatus no parasitoids reared.

No samples contained all four parasitoid species (except Tinocallis platani on Ulmus sp.). The aphidiid parasitoid $T$. pallidus appeared to be the dominant species. Only in a single case were all the three Trioxys species present in sufficient numbers for comparison (of the total of 52 specimens in sample: Kolín, $29^{\text {th }}$ June 2004, Q. rubra, in a park: T. curvicaudus $-29 \%$, T. pallidus $-42 \%$, T. tenuicaudus $-29 \%$ ).
TABLE 1. Tritrophic associations of parasitoids on M. walshii and their host range on other arboricolous calaphidine aphids in the Czech Republic. Abbreviations / parasitoids: Pf - Praon flavinode, Tc - Trioxys curvicaudus, Tp - Trioxys pallidus, TtTrioxys tenuicaudus.

\begin{tabular}{|c|c|c|c|c|c|}
\hline Aphid & Plant & $P f$ & $T c$ & $T p$ & $T t$ \\
\hline Betulaphis sp. & Betula sp. & $\mathrm{X}$ & & & \\
\hline Chromaphis juglandicola & Juglans regia & & & $\mathrm{X}$ & \\
\hline \multirow[t]{4}{*}{ Eucallipterus tiliae } & Tilia cordata & $X$ & $\mathrm{X}$ & $\mathrm{X}$ & $\mathrm{X}$ \\
\hline & Tilia europaea & $\mathrm{X}$ & & & \\
\hline & Tilia tomentosa & $\mathrm{X}$ & $\mathrm{X}$ & & \\
\hline & Tilia $\mathrm{sp}$ & $\mathrm{X}$ & & $\mathrm{X}$ & $\mathrm{X}$ \\
\hline \multirow[t]{2}{*}{ Euceraphis punctipennis } & Betula pendula & $\mathrm{X}$ & & & \\
\hline & Betula sp. & $\mathrm{X}$ & & & \\
\hline \multirow[t]{2}{*}{ Myzocallis carpini } & Carpinus betulus & $\mathrm{X}$ & & $\mathrm{X}$ & $\mathrm{X}$ \\
\hline & Carpinus sp. & & $\mathrm{X}$ & & \\
\hline Myzocallis castanicola & Quercus robur & $\mathrm{X}$ & & & \\
\hline Myzocallis coryli & Corylus avellana & $\mathrm{X}$ & $\mathrm{X}$ & $\mathrm{X}$ & $\mathrm{X}$ \\
\hline Myzocallis walshii & Quercus rubra & $\mathbf{X}$ & $\mathbf{X}$ & $\mathbf{X}$ & $\mathbf{X}$ \\
\hline Phyllaphis fagi & Fagus sylvatica & $\mathrm{X}$ & & & \\
\hline Pterocallis alni & Alnus sp. & & & $\mathrm{X}$ & \\
\hline \multirow[t]{2}{*}{ Tinocallis platani } & Ulmus effusa & & & & \\
\hline & Ulmus sp. & $\mathrm{X}$ & $\mathrm{X}$ & $\mathrm{X}$ & $\mathrm{X}$ \\
\hline \multirow[t]{2}{*}{ Tuberculatus annulatus } & Quercus robur & & & $\mathrm{X}$ & $\mathrm{X}$ \\
\hline & Quercus sp. & $\mathrm{X}$ & & $\mathrm{X}$ & \\
\hline \multirow[t]{2}{*}{ Tuberculatus sp. } & Quercus pubescens & & & & $\mathrm{X}$ \\
\hline & Quercus sp. & & & $\mathrm{X}$ & $\mathrm{X}$ \\
\hline
\end{tabular}




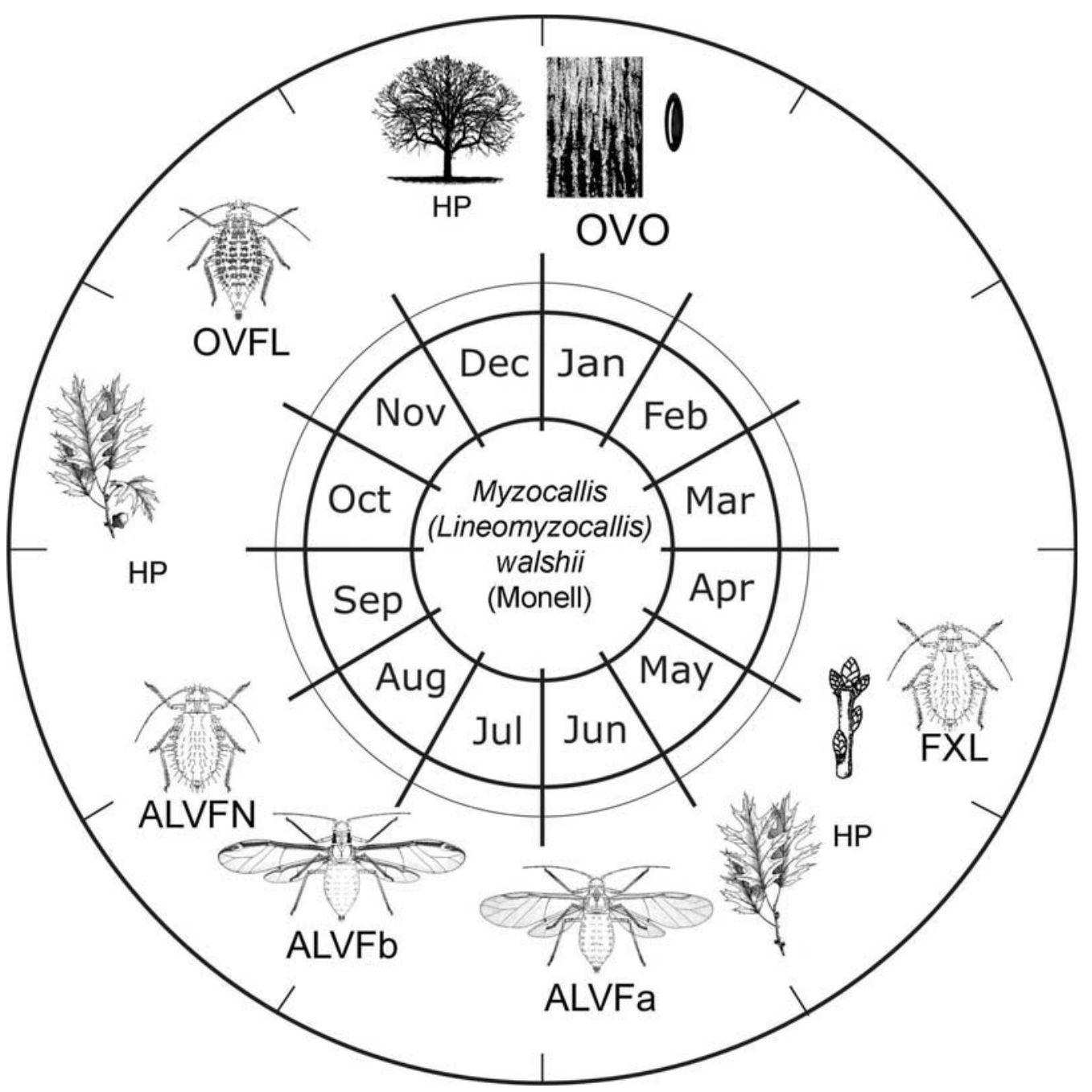

Fig. 4. Life cycle of Myzocallis (Lineomyzocallis) walshii (Mon.). Abbreviations: HP - host plant Quercus rubra L.; FXL - fundatrix nymph.; ALVFa - alate viviparous female, spring form; ALVFb - alate viviparous female, summer form; ALVFN - alate viviparous female nymph; OVFL - ovipara; OVO - egg on a red oak bark.

There were no apparent qualitative differences in the composition of parasitoid species emerging from the light and dark form of M. (Lineomyzocallis) walshii collected at the same sites. A seasonally dependent alternation / switching of parasitoids between these forms is presumed.

\section{DISCUSSION}

\section{The red oaks, Quercus rubra and other American} species

The red oak, Quercus rubra was introduced into the Czech Republic about 150 years ago, and became a popular tree because of the size, shape and coloration of its leaves in autumn. Old trees can be found in a number of arboretums all over the country (Hieke, 1984). Moreover, red oaks were planted in the forests and this also resulted in it becoming quite abundant.

Another exotic species, Q. palustris, which was relatively rarely planted in arboretums, may be found often together with $Q$. rubra. There are still other rare exotic species, such as $Q$. coccinea and other Quercus species.

\section{The aphid, Myzocallis (Lineomyzocallis) walshii}

M. (Lineomyzocallis) walshii is associated with $Q$. rubra, $Q$. velutina and $Q$. coccinea in its native home, in the USA and Canada (Quednau, 1999). It was detected as a new exotic species for the first time in Gironde dept., France (1988) (Remaudière, 1989), and later in Switzerland (1989), Spain (1991), Italy (1995), Belgium (1996), Andorra (1997) and Germany (2004). Pons at al. (2005) have recently reviewed the information on $M$. (Lineomyzocallis) walshii in Spain in the European context.

Holman \& Pintera (1977) did not record M. (Lineomyzocallis) walshii in the Czech Republic, but Holman (personal communication) collected this aphid in Třebon̆ on Quercus rubra in 1992. Our results indicate an even earlier presence of M. (Lineomyzocallis) walshii in Czech Republic. In general terms, M. (Lineomyzocallis) walshii / Q. rubra represents the case of a North American aphid species becoming accidentally introduced / established in an area following an earlier introduction / establishment of its original American host plant. M. (Lineomyzocallis) walshii is distributed all over the Czech Republic, but its 


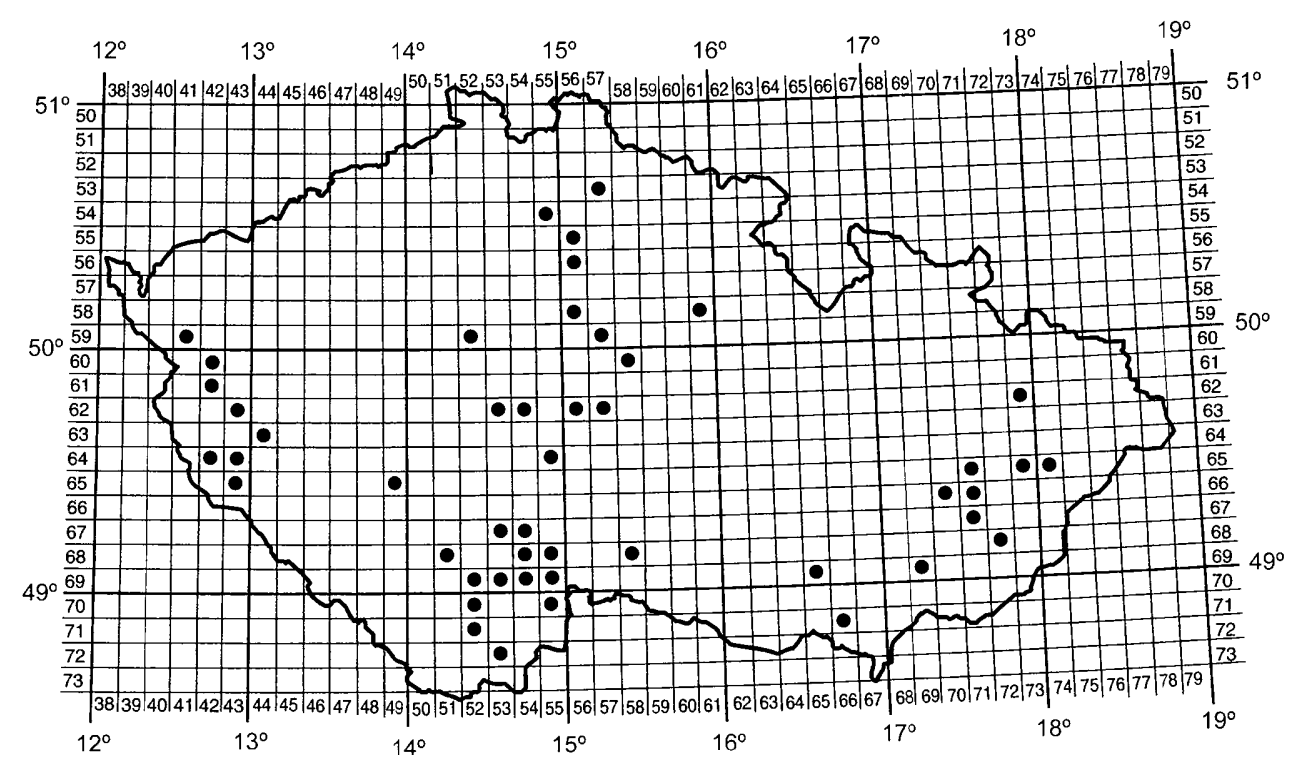

Fig. 5. Distribution of Myzocallis (Lineomyzocallis) walshii (Mon.) in the Czech Republic. The codes follow the faunistic grid mapping system (Pruner \& Míka, 1996): The first two numbers mean the row from W to E, the second two numbers is the column from $\mathrm{N}$ to $\mathrm{S}$. Black circles = positive detection of $M$. walshii in this grid. The names of individual localities are arranged following the grid numbers in the "Results".

distribution is disjunctive to some extent, reflecting the distribution of its host plant, Q. rubra. On the other hand, this type of distribution / host association indicates good dispersive capability of $M$. (Lineomyzocallis) walshii in the course of its expansion and establishment in the area. Similar distribution / association patterns of M. (Lineomyzocallis) walshii were earlier documented in Spain (Mier Durante \& Nieto Nafría, 1995, Pons et al., 2005). M. (Lineomyzocallis) walshii appears to be the dominant element in the aphid guild on Q. rubra in the Czech Republic. Its occurrence seasonally coincides with a few other less common aphid species. The seasonal occurrence of M. (Lineomyzocallis) walshii reflects its holocycly on $Q$. rubra. There are two successive population peaks in the Czech Republic, which correspond to the occurrence of the light spring and the dark summer forms of the aphid. Two different coloured forms are also recorded in Canada (Quednau, 1999). This colonization by $M$. walshii has increased the species biodiversity and associations in the Czech Republic.

\section{The parasitoids}

There were no exotic parasitoids introduced along with M. (Lineomyzocallis) walshii into Europe. Moreover, the only species it shares in common with North American populations is Trioxys pallidus on Myzocallis sp. / Q . rubra from the Pacific Northwest, U.S.A. (Pike et al., 2000), a parasitoid of West-Palearctic origin, which was introduced and became established in North America. There is also Trioxys mexicanus Starý associated with $M$. (Lineomyzocallis) walshii on Quercus sp. in Mexico (Starý \& Remaudière, 1982), which seems to represent a local native parasitoid species.

The first parasitoids of M. (Lineomyzocallis) walshii in Europe were collected in Spain, and consisted of two native species, Trioxys pallidus and T. tenuicaudus and more extensive sampling revealed a number of other calaphidine aphids / host plants associations in Spain and nearby France (Pons et al., 2005).

Earlier studies on local parasitoids (Starý, 1978, 1988, 2006) indicated they are oligophagous on some tree dwelling calaphidine aphids, including the genus Myzocallis. Similarly, the host range of the individual parasitoids species suggests an interaction with other calaphidine species on conspecific or heterospecific oaks, as well as with calaphidines on other tree species. Our results document the dynamic and nature of parasitoids' host ranges and the positive adoption of the new exotic immigrant host, M. (Lineomyzocallis) walshii, which is now included in the host range of at least Praon flavinode, Trioxys curvicaudus, T. pallidus and T. tenuicaudus. Almost all the samples that produced parasitoids were collected in park-type habitats, whereas samples from forests only occasionally produced parasitoids. This probably reflects the different densities of $M$. (Lineomyzocallis) walshii in the two habitats, with the aphid and parasitoid populations more abundant in parks compared with situations in forests. This difference appears to be a general phenomenon in many aphid-parasitoid associations in urban ecosystems (Starý, 1987).

The parasitoid complexes in Spain and in the Czech Republic are similar, with Trioxys pallidus as the dominant species. Although conspecific parasitoid populations may vary in different geographical areas depending on the local host range composition accordingly (Starý, 1978, 1988, 2006; Pons et al., 2005).

\section{M. walshii as a new exotic expansive pest in Europe}

Our observations document a rather fast expansion and an abundance of $M$. (Lineomyzocallis) walshii in the Czech Republic, at least between 1991-2004. As for many local arboricolous aphid species (for example: 
Eucallipterus tiliae (Linnaeus, 1758) on Tilia spp.; Periphyllus spp. and Drepanosiphum spp. on Acer spp.; Tuberculatus spp. on Quercus spp.; Chaitophorus spp. on Populus spp.) an abundance of M. (Lineomyzocallis) walshii results in an extensive covering of sticky honeydew on the leaves and of plants growing under red oak trees, which annoys man in urban environments. A potential usefulness of honeydew for bees has not been investigated yet.

This information on M. (Lineomyzocallis) walshii in the Czech Republic supports the initial prognosis (Remaudière, 1989) that this aphid, detected for the first time in France in 1988, will colonize all of Europe.

ACKNOWLEDGEMENTS. This was funded by Grants S5007102 and A6007105 (Grant Agency of the Czech Academy of Sciences). Thanks are due to Č. Pokorný (Lesy České republiky, Židlochovice) for permitting us to collect material in the castle arboretum, G. Remaudière (Entomology, MNHN, Paris), F.W. Quednau (Nat. Res. Canada) and N. Pérez Hidalgo (Univ. of León, Spain) for verification of sample identifications, information on distribution and host plants of $M$. (Lineomyzocallis) walshii. Some information on red oaks in the Czech Republic was kindly supplied by Š. Husák and J. Květ (Institute of Botany, Acad. Sci. CR, Třeboň) and P. Bezděčka (Nature Conservancy Centre, Luhačovice). J. Stará supplied valuable technical assistance both in the field and laboratory, and V. Regulová edited a part of the manuscript.

\section{REFERENCES}

Hieke K. 1984: [Czech Castle Parks and Their Trees]. Státní Zemědělské nakladatelství, Praha, 464 pp. [in Czech].

Holman J. \& Pintera A. 1977: Aphidoidea. Checklist of Czechoslovak Insects. Acta Faun. Entomol. Mus. Nat. Prag. (Suppl. 4) 15: 101-116.

Mier Durante M.P. \& Nieto Nafría J.M. 1995: Species of the Spanish aphid fauna with discontinuous geographical distribution. J. Aphidol. 8: 72-78.

Nieto Nafría J.M., Mier Durante M.P. \& Remaudière G. 1997: Les noms des taxa du groupe-famille chez les Aphididae (Hemiptera). Rev. Fr. Entomol. (N.S.) 19: 77-92.

Pike K.S., Starý P., Miller T., Graf G., Allison D., Boydston L. \& Miller R. 2000: Aphid parasitoids (Hymenoptera: Bra- conidae: Aphidiinae) of Northwest USA. Proc. Entomol. Soc. Wash. 102: 688-740.

Pons X., Lumbierres B. \& Starý P. 2005: Expansion of the aphid Myzocallis (Lineomyzocallis) walshii (Monell) on the red oak Quercus rubra, and adaptation of local parasitoids in the north eastern Iberian Peninsula (Hom., Aphididae, Calaphidinae: Hym., Braconidae, Aphidiinae). J. Pest Sci. 79: 17-21.

Pruner L. \& Míka P. 1996: List of settlements in the Czech Republic with associated map field codes for faunistic grid mapping system. Klapalekiana (Suppl.) 32: 1-175.

Quednau F. 1999: Atlas of the Drepanosiphine aphids of the world. Part I. Panaphidini Oestlund, 1922 - Myzocallidina Börner, 1942 (1930) (Hemiptera: Aphididae: Callaphididae). Contr. Am. Entomol. Inst. 31: 1-281.

Remaudière G. 1989: Découverte en France de l'espèce américaine Myzocallis (Lineomyzocallis) walshii (Monell) (Hom., Aphididae). Ann. Soc. Entomol. Fr. (N.S.) 25: 117.

Remaudière G. \& Quednau F. 1992: Pucerons nouveaux et peu connus de Méxique. 10e note: Le sous-genre Myzocallis (Lineomyzocallis) (Hom.: Aphididae). Ann. Soc. Entomol. Fr. (N.S.) 28: 27-36.

Remaudière G. \& Remaudière M. 1997: Catalogue des Aphididae du Monde. Homoptera: Aphidoidea. INRA, Paris, $473 \mathrm{pp}$.

StarÝ P. 1978: Parasitoid spectrum of the arboricolous callaphidid aphids in Europe (Hymenoptera, Aphidiidae; Homoptera, Aphidoidea, Callaphididae). Acta Entomol. Bohemoslov. 75: 164-177.

STARÝ P. 1987: Aphid parasitoids in an urban environment (Hymenoptera, Aphidiidae). Acta Entomol. Bohemoslov. 84: 91-10.

STARÝ P. 1988: Biotypes and interspecific relations of Trioxys parasitoids on arboricolous pest aphids (Hymenoptera: Aphididiidae, Homoptera: Callaphididae). Acta Entomol. Bohemoslov. 85: 182-190.

StarÝ P. 2006: Aphid Parasitoids of the Czech Republic (Hymenoptera: Braconidae, Aphidiinae). Academia, Prague, $430 \mathrm{pp}$.

Starý P. \& Remaudière G. 1982: New genera, species, and host records of aphid parasitoids (Hymenoptera, Aphidiidae) from Mexico. Ann. Soc. Entomol. Fr. (N.S.) 18: 107-127.

Received December 19, 2005; revised and accepted May 15, 2007 